Keyrilainen, O. (1958) Haemorrhagic cutaneous necrosis from phenylindanedione. Nordisk Medicin, 59, 567.

KIPEN, C.S. (1961) Gangrene of the breast-a complication of anticoagulant therapy. Report of two cases. New England Journal of Medicine, 265, 638.

Kirkeby, K. (1954) Agranulocytosis following treatment with phenylindanedione. Lancet, ii, 580.

Larcan, A., Bertrand, P. \& Richon, J. (1968) Accidents Cutanés Nécrotico-bulleux dus aux antivitamines $K$. Presse Médicale, 76, 1217.

Lee, H.A. \& Holden, C.E. (1964) Phenindione nephropathy with recovery: studies of morphology and renal function. Postgraduate Medical Journal, 40, 327.

Malinvaud, G., Leobardy, J. De \& Suchaud, C. (1966) Agranulocytosis survenue au cours d'un traitement par phenyl-indane-dione. Presse Médicale, 74, 18458.

Makous, N. \& VANDer Veer, J.B. (1954) Severe drug reaction to phenindione (Phenylindanedione). Journal of the American Medical Association, 155, 739.

Mehotra, T.N. (1967) Phenindione induced neuropathy. British Medical Journal, 3, 218.

Menon, I.S. (1966) Phenindione and paralytic ileus. Lancet, i, 1421.

Menon, I.S. (1968) Side effects of phenindione. British Medical Journal, 2, 622.

Metzger, H., Spruch, M. \& Fornoff, H. (1963) Agranulocytose et thrombopénie provoquées par la pindione. Nouvelle revue Française d'hématologie, 3, 603.

MoHAMED, S.D. (1965) Sensitivity reaction to phenindione, with urticaria, hepatitis and pancytopenia. British Medical Journal, 2, 1475.

Nash, A.G. (1966) Phenindione and paralytic ileus. Lancet, ii, 51 .
Pearce, J.M. (1963) Nephropathy and phenindione sensitivity. Lancet, i, 1158.

Perkins, J. (1962a) Phenindione sensitivity. Lancet, i, 127.

Perkins, J. (1962b) Phenindione jaundice. Lancet, i, 125.

Postgraduate Medical School of London (1960) A case of pulmonary hypertension. British Medical Journal, 2 , 1219.

Report to the Medical Research Council (1969) Report of short-term anticoagulant administration after myocardial infarction. British Medical Journal, 1, 335.

ShAPIRO, S. (1962) Reactions with phenindione. Lancet, ii, 52.

Sмiтh, K. (1965) Acute renal failure in phenindione sensitivity. British Medical Journal, 2, 24.

SOULIER, J.P. \& GUEGUEN, J. (1947) Action hypoprothrombinémiante (anti-K) de la phényl-indane-dione étudiée expérimentalement chez le lapin: son application chez l'homme. Comptes rendus des séances de la Société de biologie et de filiales, 141, 100.

STAFFORD, J.L. (1961) Symposium on Anticuagulant Therapy. (Ed. by Sil George Pickering). F'. 186. Harvey \& Blythe, London.

TAIT, G.B. (1960) Nephropathy during phenindione therapy. Lancet, ii, 1198.

TANSer, A.R. \& Keat, E.C.B. (1966) Phenindione-induced haemorrhagic ulcerative colitis. British Medical Journal, $1,588$.

Turiaf, J. (1965) Hépatonéphrite aigue mortelle due au phenylindanedione. Bulletins et Memoires de la Société Médicale des Hopitaux de Paris, 116, 9.

WallaCe, D.C. (1960) Sensitivity to phenindione: (Dindevan): Report of two cases. Medical Journal of Australia, 47, 934.

Zweifler, A.J., Coon, W.W. \& Willis, P.W. (1966) Bleeding during oral anticoagulant therapy. American Heart Journal, 71, 118.

\title{
Hypervitaminosis D, anaemia and renal failure
}

\author{
ROGER GABRIEL \\ M.B., M.R.C.P., D.C.H. \\ Medical Registrar
}

\author{
A. M. JOEKES \\ M.A., B.M., F.R.C.P. \\ Physician and Senior Lecturer
}

Institute of Urology, St Philip's Hospital, St Peter's Hospital Group, London, W.C.2

\author{
E. ORTON \\ M.A., B.M., B.Ch.
}

General Practitioner, 98 Harley Street, London, W.1

A 53-year-old English lady was referred in January 1967 because of reduction in renal function. The only symptom disclosed was an invariable nocturia and daytime frequency of micturition every 2 to $3 \mathrm{hr}$ during the previous year. The past history included an 18 month history of variable anaemia of 7-10 $\mathrm{g} / 100 \mathrm{ml}$ (Table 1), unexplained by barium meals, gastroscopy and laparotomy. Study of the bone marrow in June 1966 showed normal cellularity, erythropoiesis was normoblastic with normal haemoglobinization; $10 \%$ of the white cell precursors were developing eosinophils. There had been no sustained response to iron, vitamin $B_{12}$ or folic acid.

On examination: no abnormality; BP 130/80; height $5 \mathrm{ft} 4$ in $(160 \mathrm{~cm})$; weight $47 \mathrm{~kg}$.

Random and early morning urines were normal save for a specific gravity not exceeding 1010 . Haemoglobin $8.8 \mathrm{~g} / 100 \mathrm{ml}$; red blood count $3 \cdot 1$

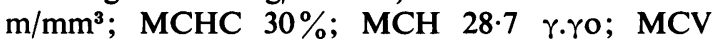
$96.7 \mathrm{cu} \mu$; reticulocytes $3.5 \%$; serum iron $105 \mu \mathrm{g} / 100$ $\mathrm{ml}$; total iron binding capacity $270 \mu \mathrm{g} / 100 \mathrm{ml}$; white 


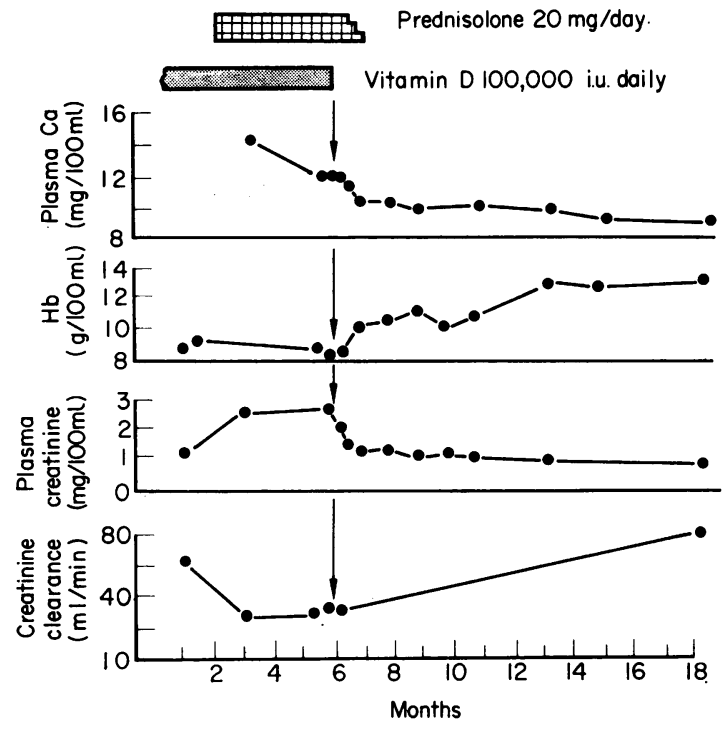

Fig. 1.

blood count $8000 / \mathrm{mm}^{3}$ with an eosinophilia of $850 / \mathrm{mm}^{3}$. Plasma creatinine $1 \cdot 1 \mathrm{mg} / 100 \mathrm{ml}$ and 24-hr creatinine clearance was $61 \mathrm{ml} / \mathrm{min}$. Two weeks after the initial haematological measurements the eosinophilia was absent and the haemoglobin had risen to $9.4 \mathrm{~g} / 100 \mathrm{ml}$ with $0.8 \%$ reticulocytes. IVP: no anatomical abnormality of the renal tract. A percutaneous renal biopsy was performed: histology was compatible with either a focal and local glomerulonephritis with moderately severe nephron loss, or an interstitial nephritis with focal glomerular changes. Although positive serological evidence was absent, the combination of anaemia with reticulocytosis, transient eosinophilia and focal glomerular changes was suggestive of a systemic sensitivity phenomenon. On this basis prednisolone $20 \mathrm{mg} /$ day was started.

Investigations were repeated after two months of corticosteroid therapy. The patient felt unwell, had headaches and anorexia. The haemoglobin was unchanged, the plasma creatinine had risen to $2.4 \mathrm{mg}$ / $100 \mathrm{ml}$ and creatinine clearance fallen to $27 \mathrm{ml} / \mathrm{min}$. Ampicillin ( $1 \mathrm{~g} /$ day) was added to the regimen on the basis that the renal interstitial changes might represent a chronic intrarenal infection. There was initially a short-lived improvement in well-being, but no change in renal function. Plasma calcium was $14.5 \mathrm{mg} / 100 \mathrm{ml}$, inorganic phosphate $3.6 \mathrm{mg} /$ $100 \mathrm{ml}$ with a total protein of $6.7 \mathrm{~g} / 100 \mathrm{ml}$. Serum alkaline phosphatase $5 \cdot 2 \mathrm{KA}$ units $/ 100 \mathrm{ml}$. Urinary calcium $325 \mathrm{mg} /$ day. (An 'average' diet was taken.)

The patient was re-admitted in mid-May of the same year for metabolic study. Renal function remained moderately severely impaired, plasma cal- cium was $12.8 \mathrm{mg} / 100 \mathrm{ml}$ with a $24-\mathrm{hr}$ urinary calcium excretion of $450-500 \mathrm{mg}$. Eventually the additional history was obtained that for the prevous 7-8 years the patient had been regularly taking 100,000 i.u. of vitamin D daily, initially prescribed for finger nail splitting. From 31 May 1967, vitamin $D$ was withdrawn and the prednisolone tapered off.

From being moderately unwell, the patient over a period of 2-3 weeks deteriorated markedly developing an agitated depression, requiring psychiatric advice as an in patient. Physical examination was negative, but as the plasma calcium at the time had fallen to $11.0 \mathrm{mg} / 100 \mathrm{ml}$, it was postulated that the symptoms were related to the changing plasma calcium. Accordingly $90 \mathrm{~g}$ of calcium gluconate were given intravenously. There was no change in condition. The depression yielded to trimipramine (Surmontil) over 1 month, during which the calcium fell to normal levels. Good health returned and was maintained after withdrawal of the antidepressant. The haemoglobin is now $13.6 \mathrm{~g} / 100 \mathrm{ml}$, plasma creatinine $0.8 \mathrm{mg} / 100 \mathrm{ml}$, and creatinine clearance 85 $\mathrm{ml} / \mathrm{min}$ (May 1970).

\section{Discussion}

The chart demonstrates the biochemical and haematological improvement following withdrawal of vitamin D. During the hypercalcaemia and hypercalcuria the skeleton was radiologically normal. Densitometry measurements by Dr F. Doyle of Hammersmith Hospital of the distal $8 \mathrm{~cm}$ of the left and right ulna bones were $434 \mathrm{mg} / \mathrm{cm}^{3}$ and $402 \mathrm{mg} /$ $\mathrm{cm}^{3}$ respectively. These figures are close to the normal mean for age (Doyle, 1961). There was therefore no evidence of bone sclerosis, and the ratio of trabecular to cortical bone was normal. Absence of sclerotic or other bone changes after 7-8 years of vitamin $\mathbf{D}$ consumption is surprising.

In some patients being investigated for renal disease the presence of calcium in needle biopsy tissue of the kidneys has led to the diagnosis of a parathyroid adenoma (Evans \& Zutshi, 1962; Joekes, 1963). In reviewing the tissue we obtained from this patient, which included twenty-two glomeruli and $5 \mathrm{~cm}$ strips of medulla, we were impressed by the absence of any calcium deposits.

The severe renal functional impairment, to approximately one quarter of normal, recovered following withdrawal of the vitamin D and return of the plasma calcium to normal. The glomerular and interstitial changes must presumably be interpreted as caused by either the hypercalcaemia or some other effect of hypervitaminosis $D$.

The anaemia is of particular interest. With both acute and chronic renal failure a marked diminution in red cell mass occurs with shortening of the red cell survival time. Acute renoprival anaemia 
develops rapidly from the time of nephrectomy and does not appear to be related to the severity of the metabolic disturbance consequent upon the renal failure. In chronic renal failure, a clinically significant anaemia does not usually develop until the blood urea is persistently above $100 \mathrm{mg} / \mathrm{ml}$ or the creatinine clearance has fallen to less than $25 \mathrm{ml} / \mathrm{min}$ (Pryor \& Joekes, 1969) although there is no direct relationship between the degree of nitrogen retention and the anaemia (Stewart, 1967). In the present case the serial blood ureas (Table 1) demonstrate that the

TABLE 1. Female aged 53 years

\begin{tabular}{lcc}
\hline Date & $\begin{array}{c}\text { Haemoglobin } \\
(\mathrm{g} / 100 \mathrm{ml})\end{array}$ & $\begin{array}{c}\text { Blood urea } \\
(\mathrm{mg} / 100 \mathrm{ml})\end{array}$ \\
\hline Jan 1964 & $13 \cdot 0$ & - \\
Aug 1965 & $9 \cdot 8$ & - \\
May 1966 & $9 \cdot 8$ & 30 \\
Sept 1966 & $7 \cdot 4$ & 63 \\
Oct 1966 & $14 \cdot 0$ & 46 \\
Jan 1967 & $8 \cdot 4$ & 50 \\
May 1967 & $8 \cdot 2$ & 94 \\
Oct 1967 & 11.0 & 59 \\
June 1968 & $13 \cdot 6$ & 43 \\
\hline
\end{tabular}

anaemia is not dependent on the severity of the metabolic disturbance due to the renal involvement. It must be postulated that hypervitaminosis $D$ is a direct or indirect cause of the anaemia, possibly acting by interfering with the renal production of some substance affecting erythropoiesis or red cell survival. Regrettably no observations were made of the red cell mass or red cell survival time. There is no evidence from patients with primary hyperparathyroidism that hypercalcaemia per se leads to an anaemia. We are unable to accept the view of Davies (1960) that with vitamin D poisoning 'an anaemia invariably occurs and is associated with the uraemia'. Scharfman \& Propp (1956) described four cases in which vitamin $\mathrm{D}$ intoxication presented with a normochromic, normocytic anaemia. One of these patients, whilst anaemic, had normal renal function and the anaemia resolved on withdrawal of the vitamin. The fact that vitamin $D$ causes an anaemia directly or indirectly in the presence of normal renal function is not demonstrated in the papers of vitamin D poisoning (Kaufman, Beck \& Wiseman, 1947; Howard \& Meyer, 1948).
It should be emphasized that the recovery of the haemoglobin concentration in our patient, followed withdrawal of the vitamin and occurred without any haematinics.

Vitamin D intoxication may present as a neuropsychiatric problem (Lehrer \& Levitt, 1960) or mental depression may complicate a pre-existing hypercalcaemia (Chaplin, Clark \& Ropes, 1951) on withdrawal of the vitamin the mental abnormality usually resolves (Anderson, Cooper \& Naylor, 1968). In our patient there was no mental ill health until the vitamin was stopped and this was short lived.

\section{Acknowledgments}

We wish to thank Miss F. Wadsworth, Medical Artist and Mr R. E. Bartholomew, Photographer, of the Institute of Urology for preparing and processing the charts. We are grateful to Dr G. A. Rose and his staff for the biochemical estimations.

\section{References}

Anderson, D.C., Cooper, A.F. \& Naylor, G.T. (1968) Vitamin D intoxication with hypernatraemia, Potassium and water depletion and mental depression. British MedicaJournal, 4, 744.

Chaplin, H., Clark, L.D. \& Ropes, M.W. (1951) Vitamin D intoxication. American Journal of Medical Science, 221, 369.

DAvies, P. (1960) Vitamin D poisoning: a report of two cases. Annals of Internal Medicine, 53, 1250.

DOYLE, F.H. (1961) Ulna bone mineral concentration in metabolic bone disease. British Journal of Radiology, 34, 698.

Evans, B.R. \& Zutski, D. (1962) Hyperparathyroidism re vealed by renal biopsy. British Medical Journal, 1, 1739.

HowARD, J.E. \& MEYER, R.J. (1948) Intoxication with Vitamin D. Journal of Clinical Endocrinology, 8, 895.

JoEKeS, A.M. (1963) Two unpublished cases.

Kaufman, P., BeCK, R.D. \& Wiseman, R.D. (1947) Vitamin $\mathrm{D}$ (Enteron) theraphy in arthritis. Journal of the American Medical Association, 134, 688.

LEHRER, G.M. \& LEVITT, M.F. (1960) Neuropsychiatric presentation of hypercalcaemia. Journal of the Mount Sinai Hospital, 27, No. 1.10.

Pryor, J.S. \& Joekes, A.M. (1969) Anaemia in renal disease. British Journal of Urology, 41, No. 4. Supplt, p. 88.

Scharfman, W.B. \& Propp, S. (1956) Anaemia associated with Vitamin D intoxication. New England Journal of Medicine, 255, 1207.

STEWART, J.H. (1967) Haemolytic anaemia in acute and chronic renal failure. Quarterly Journal of Medicine, 141, 85. 